\title{
Genetic variability of selected Passiflora alata genotypes based on the physical characteristics of fruits
}

\author{
Ana Claudia Alves D'Abadia ${ }^{*}$ (D) Fábio Gelape Faleiro ${ }^{2}$ (D) Ana Maria Costa ${ }^{2}$ (D) \\ Nilton Tadeu Vilela Junqueira ${ }^{2}$ Marcelo Fideles Braga ${ }^{2}$ D
}

${ }^{1}$ Programa de Pós-graduação em Agronomia, Universidade de Brasília (UnB), 70910-900, Brasília, DF, Brasil. E-mail: anadabadia@yahoo.com.br. ${ }^{*}$ Corresponding author.

${ }^{2}$ Empresa Brasileira de Pesquisa Agropecuária (Embrapa), Embrapa Cerrados, Planaltina, DF, Brasil.

ABSTRACT: Over several past centuries, specific plant populations have been carefully selected to filter strains with higher agronomic performance. Genetic variability is most essential for successful selection. The Passiflora genus offers great inter-and intra-specific variability. This study aimed to evaluate the physical characteristics of the genotypes of the elite passion fruit (Passiflora alata) for selection purpose. We considered the physical traits of fruit mass, longitudinal and equatorial diameters, peel thickness and color, and pulp mass and volume without and with seeds and pulp yield. The sources of variation for the analysis of variance included the fruits of 8 elite genotypes, with 3 replications, whose means were compared by Tukey's test at 1\% probability. We also performed multivariate analysis and correlation between these characteristics. Statistical differences were noted between elite genotypes for most of the tested traits. The elite 7 genotype presented with the highest seedless pulp yield in relation to the fruit and the largest fruit mass. Cluster analysis and graphic dispersion revealed a tendency for clustering of the elite genotypes based on their fruit shape. The tested population showed genetic variability, which allowed new selection cycles toward gaining pulp yield and fruit mass.

Key words: Passiflora, sweet passion fruit, clustering, main components.

Variabilidade genética de genótipos selecionados de Passiflora alata baseada em características físicas de frutos

RESUMO: Há séculos, populações de plantas vem sendo selecionadas a fim de se obter linhagens com maior desempenho agronômico. Para o sucesso da seleção, a variabilidade genética é essencial, sendo que dentro do gênero Passiflora há grande variabilidade inter e intraespecifica. Neste trabalho, objetivou-se avaliar as características fisicas de frutos de genótipos elite de maracujazeiro-doce (Passiflora alata) para fins de seleção. Foram avaliadas a massa, diâmetros longitudinal e equatorial de frutos, espessura e coloração da casca e massa e volume de polpa com e sem sementes e rendimentos de polpa. As fontes de variação para análise de variância foram os frutos de oito genótipos elite, com três repetições, cujas médias foram comparadas pelo teste de Tukey a 1\% de probabilidade. Foram realizadas ainda análises multivariadas e de correlação entre as características. Houve diferenças estatísticas entre os genótipos elite para a maioria das características avaliadas. O genótipo elite sete foi o que apresentou maior rendimento de polpa sem sementes, em relação ao fruto e maior massa de fruto. Análises de agrupamento e dispersão gráfica evidenciaram uma tendência de agrupamento dos genótipos elite com base no formato dos frutos. A população apresenta variabilidade genética, que permite novos ciclos de seleção para ganho em rendimento de polpa e massa dos frutos. Palavras-chave: Passiflora, maracujá-doce, agrupamento, componentes principais.

\section{INTRODUCTION}

Much work has been performed in the domestication and genetic improvement of several cultivated plant species with the main aim of selecting species that are more productive, more resistant to pests and diseases, better ability to adapt, and greater homogeneity (FERREIRA \& RANGEL, 2005). For instance, the genus Passiflora L. (Passifloraceae) included more than 500 species of passion fruit, which makes it apt for use in breeding programs, considering that the available genetic variability allows for the selection and genetic recombination with these species (FERREIRA, 2005; REFLORA, 2018). Passion fruit variability can be evidenced by morphological, agronomic, ecological, and molecular characteristics, and fruit characteristics are the variabilities that contributed the most to genetic variability (OLIVEIRA et al., 2017).

Passiflora alata Curtis is a passion fruit species cultivated in Brazil for the main purpose of producing raw material (i.e., leaves), specifically for the herbal and cosmetic industries (COSTA, 2017) as well as for the supply of fruits for fresh consumption (FALEIRO et al., 2016). The sweet passion fruit crop is the second-most cultivated fruit species in Brazil (JUNQUEIRA et al., 2005). Whereas, in the state of Goiás, the value of the fruit reached an average of 4-times that paid for the commercial sour passion fruit in 2017 (Passiflora edulis Sims) (CEASA-GO, 2017). 
With increasing interest both from the producers as well as the consumer market with regard to this species, a growing need has been identified for more homogeneous and productive cultivars as well as for appropriate production technologies in fruit production (BRAGA et al., 2005). Foreseeing the market potential of this species (MACHADO et al., 2017), the Embrapa's passion fruit has been genetically improved and made available to the producers as the first commercial variety (registered as BRS Mel do Cerrado [BRSMC]) in 2017 (FALEIRO, et al., 2017).

The naturally available passion fruit offers great interspecific variability (FERREIRA, 2005), as has been evidenced by the differences in its fruit morphology (MARTINS et al., 2003), specially with large variation in the size and shape of fruits (BRAGA et al., 2005). MELETTI et al. (2003) also verified that accessions of passion fruit selected for the cultivation presented with morphological characteristics that were superior to those of the native accessions of $P$. alata. Thus, it is expected that more selected an elite genotype is, smaller is the population presenting with the morphological differences of fruits among the tested plants.

Recurring selection resulted in continuous improvement of the passion fruit population among Embrapa and partners. During this process, the elite genotypes with higher yield, better fruit characteristics (such as higher fruit mass, pulp and shell color, firm peel, high soluble solids content, and fruit shape) and greater disease resistance were selected.

This study aimed to evaluate the variability of elite genotypes within the population of the last recurrent selection cycle that originated from the cultivar P. alata BRS Mel do Cerrado (BRS MC) based on the physical characteristics of fruits and considering the use of such elite genotypes as the breeding stock for future breeding programs.

\section{MATERIALS AND METHODS}

We analyzed 8 elite genotypes obtained from the recurrent selection population that originated from the sweet passion fruit cultivar BRS Mel do Cerrado (launched in 2017). This cultivar was obtained through population improvement for increasing its productivity, fruits with adequate physical and chemical characteristics (such as oboval fruits with an average mass of $300 \mathrm{~g}$ ), orange yellow flesh, high soluble solids content, edible peel, and greater disease tolerance. The first selection and recombination cycles were conducted in 1999 using P. alata accessions and populations from different origins. Population genetic improvement was performed via mass selection among and within halfsib families. Matrices and superior progenies were selected and applied in the generation of the new cultivar (FALEIRO et al., 2017).

Elite matrices of the last selection cycle of the cultivar BRS Mel do Cerrado were cloned and field grown in the Embrapa Cerrados Fruit Support Unit, $15^{\circ} 36^{\prime} 13.02^{\prime}$ 'S 4 47 43'17.34”O, and approximate altitude of $1050 \mathrm{~m}$, Planaltina, Brasilia, DF. The opening of the pit with dimensions of 60$\mathrm{cm}$ depth and $40 \mathrm{~cm}$ diameter was performed using a drill bit. Planting fertilization was performed with dolomitic limestone to increase the base saturation to $50 \% ; \mathrm{P}_{2} \mathrm{O}_{5}$ (source: Simple Superphosphate) $250 \mathrm{~g} /$ pit; $\mathrm{N}$ (source: ammonium sulphate) $100 \mathrm{~g} /$ pit; $\mathrm{K}_{2} \mathrm{O}$ (source: Potassium chloride) $100 \mathrm{~g} /$ pit; micronutrients (source: FTE BR12) $100 \mathrm{~g} /$ well; organic matter (source: chicken litter) $10 \mathrm{~L} /$ pit.

In September 2014, an experiment was established in the field using 3.5-month-old seedlings that were planted under drip irrigation conditions, with an interval of $2.5 \mathrm{~m}$ among plants and $3.0 \mathrm{~m}$ among rows. From this cultivation experiment, 8 elite $P$. alata genotypes were selected based on visual differences in the fruit shape (such as elongated and rounded shape) (Figure 1). In March 2015, the fruits were evaluated at their physiological maturity stage and harvested from the plants when they developed at least $30 \%$ of yellow skin color.

The physical data collected included fruit mass $(\mathrm{g})$, fresh and dry peel mass $(\mathrm{g})$ and pulp mass [without and with seeds $(\mathrm{g})$ ] determined by the means of a centesimal semi-analytical balance (Ohaus Adventurer ${ }^{\circledR}$ ); longitudinal and equatorial diameter $(\mathrm{cm})$, shell thickness $(\mathrm{mm})$ determined using digital caliper (Stainless Hardened ${ }^{\circledR}$ ); fruit shape (ratio between longitudinal and equatorial diameter); percent water content of the shell performed based on the ratio of fresh and dry weight of the shell (dry mass: obtained by drying at $60^{\circ}$ until reaching constant mass); pulp volume without and with seeds $(\mathrm{mL})$ determined by means of a 100-mL graduated beaker; pulp yield, calculated as percent values for $\mathrm{m} / \mathrm{m}$ ratio (YPS) and $\mathrm{v} / \mathrm{v}$ (YV) of seedless pulp/seed pulp and $\mathrm{m} / \mathrm{m}$ ratio of seedless pulp/fruit (YSF); peel coloring was performed directly on the fruit at 5 different points using a portable spectrophotometer (HunterLab ${ }^{\circledR}$; MiniScan EZ) that measured values of L (luminosity), a (indicative of green or red), and $b$ (indicative of yellow or blue); the mean values of $a$ and $b$ were used to calculate the chromaticity (color 


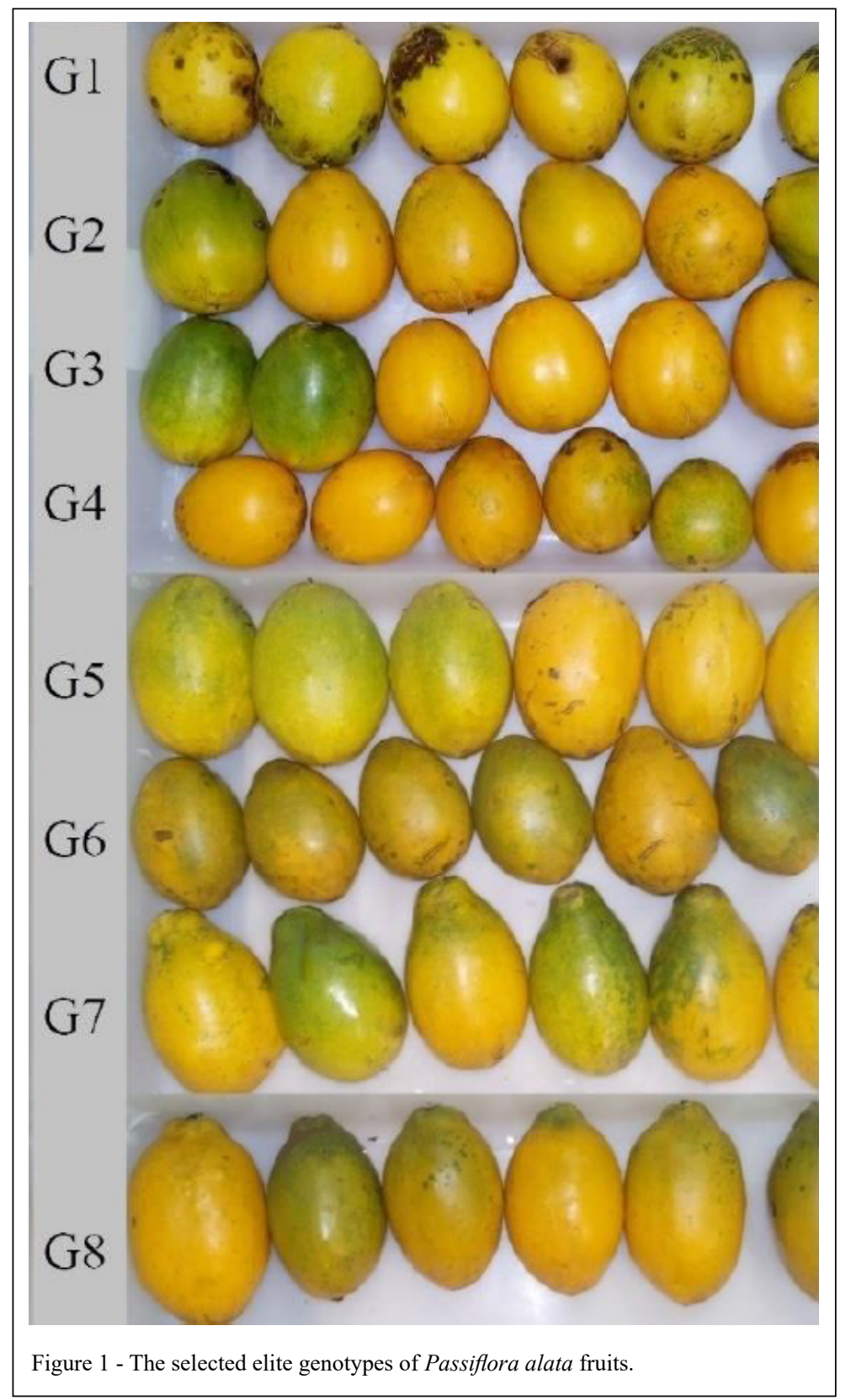

intensity) and hue angle [color hue $\left.\left({ }^{\circ} \mathrm{h}\right)\right]$ as described by MCGUIRE (1992).

The experiment was analyzed at the Embrapa Cerrados Food Science and Technology laboratory via a completely randomized design using 3 replications for each elite genotype, and each repetition consisted of an average of 2 fruits.

The data obtained data were subjected to the analysis of variance, and the averages were compared using Tukey's test at $1 \%$ significance. Genetic distances among the selected 8 elite $P$. alata genotypes were calculated based on all of the 17 evaluated traits. The estimates of genetic distances were based on the Mahalanobis distance using the Genes computer program (CRUZ, 2013). Pearson correlations were calculated among the 17 characteristics using the Genes (CRUZ, 2013).

Ciência Rural, v.50, n.2, 2020. 
Based on the genetic distance matrix, the elite genotype grouping analyzes were performed via dendrogram using the Unweighted Pair-Group Method with Arithmetic Avarages (UPGMA) as the clustering criterion as well as graphic dispersion based on the multidimensional scales using the method of main coordinates with the SAS (SAS INSTITUTE INC., 2008) and Statistica (STATSOFT INC., 2005). The relative contribution of each trait evaluated for divergence of elite genotypes was estimated based on the SINGH coefficient (1981) using the Genes (CRUZ, 2013).

\section{RESULTS AND DISCUSSION}

Differences were noted between elite genotypes for most of the evaluated physical traits (Table 1). Table 2 shows that the elite genotypes G2, G3, G5, and G7 presented fruits with mass $>200 \mathrm{~g}$, and fruits with lower mass were verified in the elite genotypes G1, G4, and G8.

The elite genotypes G5 and G7 were among the ones that showed prominence in most of the studied characters. The G5 genotype presented with larger equatorial diameter (Table 2), fresh and dry shell mass (Table 3), pulp mass with seeds (Table 4), as well as fruits with higher luminosity (Table 5). Among all tested genotypes, G7 showed the best results with respect to the longitudinal diameter, presenting longer fruits (LD/ED ratio; table 2), pulp mass and volume without and with seeds, and higher seedless pulp yield in relation to the fruit (Table 4).

The elite genotypes G1, G4, and G6 were fruits with the lowest mass values, longitudinal and equatorial diameters being the least elongated because they had the lowest LD/ED ratio, and the lowest fresh and dry shell mass (Table 2). The mass and volume of the seeded and seedless pulp and lower yield of the seedless pulp relative to the fruits are given in table 4 .

Correlation analyses (Table 6) revealed that higher the fruit and seedless pulp mass, greater is the seedless pulp yield relative to the fruit. Thus, by estimating the fruit mass, it was possible to correlate to a higher yield of fruit pulp. In addition, elite genotypes with longer fruits showed a thinner shell

Table 1 - Summary of variance analysis of the physical characteristics of fruits of 8 elite genotypes selected from the Passiflora alata Curtis.

\begin{tabular}{|c|c|c|c|c|c|c|c|}
\hline \multirow[t]{2}{*}{ Source of variation } & \multirow[t]{2}{*}{ d.f. ${ }^{1}$} & \multicolumn{6}{|c|}{ 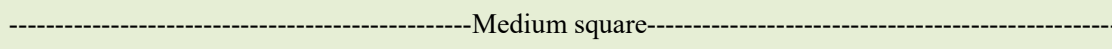 } \\
\hline & & FM (g) & $\mathrm{LD}(\mathrm{cm})$ & $\mathrm{ED}(\mathrm{cm})$ & $\mathrm{LD} / \mathrm{ED}$ & FPM (g) & $\mathrm{BDM}(\mathrm{g})$ \\
\hline Treatments & 7 & 3133.10 & 531.88 & 32.34 & 0.10 & 1831.35 & 14.82 \\
\hline Residue & 16 & 142.21 & 10.77 & 4.11 & 0.002 & 79.23 & 1.09 \\
\hline Total & 23 & - & & - & - & - & - \\
\hline $\mathrm{F}$ & & $22.03^{*}$ & $49.38^{*}$ & $7.86^{*}$ & $38.13^{*}$ & $23.11^{*}$ & $13.54^{*}$ \\
\hline \multirow[t]{2}{*}{ Source of variation } & d.f. & \multicolumn{6}{|c|}{ 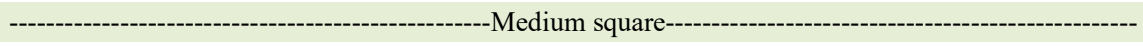 } \\
\hline & & BW (\%) & $\mathrm{ST}(\mathrm{mm})$ & PMS (g) & VPS (mL) & PM (g) & PV (mL) \\
\hline Treatments & 7 & 1.28 & 7.52 & 1282.05 & 1335.65 & 517.87 & 484.79 \\
\hline Residue & 16 & 0.09 & 0.19 & 105.93 & 94.99 & 34.45 & 37.76 \\
\hline Total & 23 & - & - & - & - & - & - \\
\hline $\mathrm{F}$ & & $12.87^{*}$ & $37.60^{*}$ & $12.10^{*}$ & $14.06^{*}$ & $15.03^{*}$ & $12.83^{*}$ \\
\hline \multirow[t]{2}{*}{ Source of variation } & d.f. & \multicolumn{6}{|c|}{ 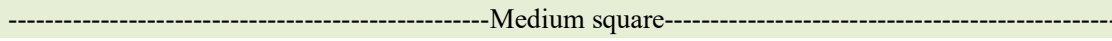 } \\
\hline & & YPS $(\%)$ & YV (\%) & YSF (\%) & $\mathrm{L}$ & $\mathrm{C}$ & $\operatorname{HUE}\left({ }^{\circ}\right)$ \\
\hline Treatments & 7 & 114.84 & 112.19 & 63.53 & 53.47 & 67.94 & 100.14 \\
\hline Residue & 16 & 45.26 & 48.27 & 7.89 & 3.62 & 13.01 & 52.64 \\
\hline Total & 23 & - & - & - & - & - & - \\
\hline $\mathrm{F}$ & & $2.5^{\mathrm{ns}}$ & $2.32^{\mathrm{ns}}$ & $8.04^{*}$ & $14.74^{*}$ & $5.22^{*}$ & $1.90^{\mathrm{ns}}$ \\
\hline
\end{tabular}

FM - fruit mass; LD - longitudinal diameter; ED - equatorial diameter; LD / ED - longitudinal / equatorial diameter ratio; FPM - fresh peel mass; BDM - bark dry mass; BW - bark water content; ST - shell thickness; PMS - pulp mass with seed; VPS - volume of pulp with seed; PM - seedless pulp mass (g); PV - pulp volume without seed; YPS- yield of pulp without seed in relation to pulp with seed; YV yield of seedless pulp volume in relation to seeded pulp; YSF - yield of seedless pulp mass in relation to fruit mass; L - luminosity; C chroma; HUE - angle hue; ${ }^{1}$ :degrees of freedom; *, ns: Significant or not significant at $5 \%$ probability, respectively, by the F test. 
Table 2 - The average values of fruit mass characteristics, longitudinal (LD) and equatorial diameter (ED), and the LD/ED ratio of fruits of 8 elite genotypes selected from the Passiflora alata Curtis.

\begin{tabular}{|c|c|c|c|c|}
\hline Genotypes & Fruit Dough (g) & $\mathrm{LD}(\mathrm{cm})$ & $\mathrm{ED}(\mathrm{cm})$ & LD/ED \\
\hline G1 & $168.43 \mathrm{c}$ & $7.96 \mathrm{e}$ & $7.03 \mathrm{ab}$ & $1.13 \mathrm{~d}$ \\
\hline G2 & $211.75 \mathrm{ab}$ & 8.94 cde & $7.49 \mathrm{a}$ & $1.19 \mathrm{bcd}$ \\
\hline G3 & $212.28 \mathrm{ab}$ & $8.52 \mathrm{de}$ & $7.23 \mathrm{ab}$ & $1.18 \mathrm{~cd}$ \\
\hline G4 & $151.21 \mathrm{c}$ & $7.82 \mathrm{e}$ & $6.64 \mathrm{~b}$ & $1.17 \mathrm{~cd}$ \\
\hline G5 & $239.17 \mathrm{a}$ & $10.06 \mathrm{bc}$ & $7.52 \mathrm{a}$ & $1.33 \mathrm{bc}$ \\
\hline G6 & $180.39 b c$ & $9.23 \mathrm{~cd}$ & $6.74 \mathrm{~b}$ & $1.37 \mathrm{~b}$ \\
\hline G7 & $219.20 \mathrm{ab}$ & $11.41 \mathrm{a}$ & $7.19 \mathrm{ab}$ & $1.58 \mathrm{a}$ \\
\hline G8 & $157.46 \mathrm{c}$ & $10.94 \mathrm{ab}$ & $6.87 \mathrm{ab}$ & $1.59 \mathrm{a}$ \\
\hline $\mathrm{CV} \%$ & 6.19 & 3.5 & 2.85 & 3.9 \\
\hline
\end{tabular}

Means followed by the same letter in the column do not differ from each other by the Tukey's test at $1 \%$ probability.

1 thickness. VASCONCELLOS et al. (2001) also noted 2 that $P$. alata fruits with higher mass also had greater 3 fresh and dry shell masses.

4 The elite genotypes G4 and G8, which had 5 lower bark water content, also showed the lowest bark 6 thickness values (Table 3 ), and a significant positive 7 correlation was noted between these characteristics 8 (Table 6). Regarding the format during plant selection, 9 the elite genotypes G1-G4 were selected considering 10 their rounded format, and from G5 to G8, because they were longer. As can be seen in table 2, the elite genotypes G5-G8 had higher values. However, the G5 and G6 elite genotypes differed significantly from the elongated elite genotypes G7 and G8.

As per table 2, fruit mass dimensions presented with values within the range recorded for 5 P. alata populations by MARTINS et al. (2003) and close to the values verified by VASCONCELLOS et al. (2001) and ALVES et al. (2012). The fruit mass was also within the values reported in cv. BRS Mel do

Table 3 - The average values of fresh (FPM) and dry (BDM) peel characteristics, house thickness (ST), and peel water content (BW) of fruits of 8 elite genotypes selected from the Passiflora alata Curtis.

\begin{tabular}{lcccc}
\hline Genotypes & FPM $(\mathrm{g})$ & BDM $(\mathrm{g})$ & ST $(\mathrm{mm})$ & BW (\%) \\
\hline G1 & $143.25 \mathrm{bcd}$ & $10.64 \mathrm{c}$ & $14.00 \mathrm{a}$ & $92.57 \mathrm{a}$ \\
G2 & $172.74 \mathrm{ab}$ & $14.65 \mathrm{ab}$ & $13.82 \mathrm{ab}$ & $91.51 \mathrm{abcd}$ \\
G3 & $157.20 \mathrm{ab}$ & $13.51 \mathrm{abc}$ & $13.64 \mathrm{ab}$ & $91.41 \mathrm{bcd}$ \\
G4 & $113.14 \mathrm{~d}$ & $10.32 \mathrm{c}$ & $12.27 \mathrm{~b}$ & $90.85 \mathrm{~d}$ \\
G5 & $185.36 \mathrm{a}$ & $16.61 \mathrm{a}$ & $13.81 \mathrm{ab}$ & $91.05 \mathrm{~cd}$ \\
G6 & $146.73 \mathrm{bc}$ & $11.30 \mathrm{bc}$ & $13.04 \mathrm{ab}$ & $92.29 \mathrm{ab}$ \\
G7 & $162.70 \mathrm{ab}$ & $13.04 \mathrm{abc}$ & $12.77 \mathrm{ab}$ & $91.98 \mathrm{abc}$ \\
G8 & $120.36 \mathrm{~cd}$ & $10.99 \mathrm{bc}$ & $9.20 \mathrm{c}$ & $90.86 \mathrm{~d}$ \\
\hline CV\% & 5.92 & 8.27 & 3.48 & 0.34 \\
\hline
\end{tabular}

Means followed by the same letter in the column do not differ from each other by the Tukey's test at $1 \%$ probability. 
Table 4 - The average values of pulp mass characteristics with seeds (PMS) and seedless (PM), pulp volume with seeds (VPS) and seedless (VS), and pulp yield (YSF, YPS, and YV) ${ }^{1}$ of fruits of 8 elite genotypes selected from the Passiflora alata Curtis.

\begin{tabular}{lccccccc}
\hline Genotype & PMS (g) & PM $(\mathrm{g})$ & VPS $(\mathrm{mL})$ & PV (mL) & YSF (\%) & YPS (\%) & YV (\%) \\
\hline G1 & $23.68 \mathrm{~b}$ & $11.93 \mathrm{~d}$ & $25.08 \mathrm{~d}$ & $12.20 \mathrm{c}$ & $13.76 \mathrm{~b}$ & $48.14 \mathrm{a}$ & $46.24 \mathrm{a}$ \\
G2 & $36.97 \mathrm{ab}$ & $18.73 \mathrm{bcd}$ & $38.42 \mathrm{bcd}$ & $19.47 \mathrm{abc}$ & $17.66 \mathrm{ab}$ & $51.76 \mathrm{a}$ & $51.98 \mathrm{a}$ \\
G3 & $49.85 \mathrm{a}$ & $22.34 \mathrm{abc}$ & $48.58 \mathrm{abc}$ & $22.25 \mathrm{abc}$ & $21.12 \mathrm{ab}$ & $45.09 \mathrm{a}$ & $46.08 \mathrm{a}$ \\
G4 & $34.33 \mathrm{ab}$ & $16.23 \mathrm{bcd}$ & $35.83 \mathrm{bcd}$ & $17.58 \mathrm{bc}$ & $21.38 \mathrm{ab}$ & $47.09 \mathrm{a}$ & $48.96 \mathrm{a}$ \\
G5 & $49.98 \mathrm{a}$ & $25.64 \mathrm{ab}$ & $52.50 \mathrm{ab}$ & $25.00 \mathrm{ab}$ & $21.53 \mathrm{ab}$ & $51.34 \mathrm{a}$ & $47.71 \mathrm{a}$ \\
G6 & $30.53 \mathrm{~b}$ & $11.80 \mathrm{~d}$ & $31.75 \mathrm{~cd}$ & $11.95 \mathrm{c}$ & $13.04 \mathrm{~b}$ & $38.49 \mathrm{a}$ & $37.52 \mathrm{a}$ \\
G7 & $52.16 \mathrm{a}$ & $29.82 \mathrm{a}$ & $55.65 \mathrm{a}$ & $29.84 \mathrm{a}$ & $27.19 \mathrm{a}$ & $57.05 \mathrm{a}$ & $53.48 \mathrm{a}$ \\
G8 & $36.84 \mathrm{ab}$ & $14.50 \mathrm{~cd}$ & $39.40 \mathrm{abcd}$ & $14.45 \mathrm{bc}$ & $18.43 \mathrm{ab}$ & $39.99 \mathrm{a}$ & $36.70 \mathrm{a}$ \\
\hline CV\% & 13.09 & 15.5 & 11.91 & 16.09 & 14.58 & 14.2 & 10.01 \\
\hline
\end{tabular}

Means followed by the same letter in the column do not differ from each other by the Tukey's test at $1 \%$ probability. ${ }^{1}$ YSF - yield of seedless pulp mass in relation to fruit mass (\%); YPS - yield of pulp without seed in relation to pulp with seed (\%); YV - yield of seedless pulp volume relative to seed pulp (\%).

Cerrado (FALEIRO et al., 2017), because the fruits belonged to the last selection cycle of this cultivar.

As depicted by table 2, it seems possible to have verified that the fruits of the elite G5 genotype had larger mass and superior value of the seed pulp mass (Table 4) The genotypes G3 and G7 had higher mass. The elite G1 genotype presented with lower values of fruit mass and lower mass value (Table 2) and pulp volume, both without and with seeds (Table 4).
The mean values of seed pulp mass (Table 4) were close to the values recorded by VASCONCELOS et al. (2001) for one of the 3 types of fruits classified in their research. These authors also reported that larger fruits have greater seeded pulp.

With regard to peel thickness and seed pulp mass, their respective higher values can be considered as a positive factor for the selection of $P$.

Table 5 - The average values of fruit peel color characteristics, related to luminosity, chroma, and hue angle of 8 elite genotypes selected from the Passiflora alata Curtis.

\begin{tabular}{lccr}
\hline Genotype & Lightness & Chroma & Hue angle \\
\hline G1 & $65.69 \mathrm{a}$ & $51.53 \mathrm{ab}$ & $76.42 \mathrm{a}$ \\
G2 & $61.58 \mathrm{ab}$ & $53.26 \mathrm{ab}$ & $70.07 \mathrm{a}$ \\
G3 & $62.86 \mathrm{a}$ & $51.74 \mathrm{ab}$ & $73.22 \mathrm{a}$ \\
G4 & $62.20 \mathrm{ab}$ & $58.00 \mathrm{a}$ & $67.78 \mathrm{a}$ \\
G5 & $62.87 \mathrm{a}$ & $52.97 \mathrm{ab}$ & $72.41 \mathrm{a}$ \\
G6 & $52.70 \mathrm{c}$ & $41.00 \mathrm{~b}$ & $72.37 \mathrm{a}$ \\
G7 & $60.49 \mathrm{ab}$ & $51.16 \mathrm{ab}$ & $75.18 \mathrm{a}$ \\
G8 & $55.84 \mathrm{bc}$ & $50.42 \mathrm{ab}$ & $71.56 \mathrm{a}$ \\
CV\% & 3.14 & 7.03 & 10.34 \\
\hline
\end{tabular}

Means followed by the same letter in the column do not differ from each other by the Tukey's test at $1 \%$ probability. 
Table 6 - The estimates of Pearson correlation coefficients between the phenotypic character pairs of 8 elite genotypes selected from the last selection cycle of the cultivar Passiflora alata BRS Mel do Cerrado.

\begin{tabular}{|c|c|c|c|c|c|c|c|c|c|c|c|c|c|c|c|c|c|}
\hline & LD & ED & $\begin{array}{c}\mathrm{LD} / \mathrm{E} \\
\mathrm{D}\end{array}$ & FPM & BDM & BW & ST & PMS & VPS & PM & PV & YPS & YV & YSF & $\mathrm{L}$ & $\mathrm{C}$ & hue \\
\hline $\begin{array}{l}\mathrm{F} \\
\mathrm{M}\end{array}$ & 0.35 & $0.83^{* *}$ & 0.05 & $0.95^{* *}$ & $0.92^{* *}$ & -0.01 & $0.53^{* *}$ & $0.75^{* *}$ & $0.75^{* *}$ & $0.77^{* *}$ & $0.73^{* *}$ & $0.44^{*}$ & 0.36 & $0.42^{*}$ & 0.17 & -0.06 & -0.07 \\
\hline $\begin{array}{l}\text { L } \\
\text { D }\end{array}$ & & 0.22 & $0.93^{* *}$ & 0.25 & 0.30 & -0.15 & $-0.46^{*}$ & $0.49^{*}$ & $0.57^{* *}$ & $0.47^{*}$ & $0.43^{*}$ & 0.13 & -0.07 & 0.39 & $-0.41^{*}$ & -0.22 & -0.32 \\
\hline $\begin{array}{l}\text { E } \\
\text { D }\end{array}$ & & & -0.12 & $0.86^{* *}$ & $0.84^{* *}$ & -0.04 & $0.47^{*}$ & $0.52^{* *}$ & $0.52^{* *}$ & $0.63^{* *}$ & $0.61^{* *}$ & $0.62^{* *}$ & $0.56^{* *}$ & 0.36 & 0.33 & 0.13 & -0.008 \\
\hline $\begin{array}{l}\mathrm{L} \\
\mathrm{D} / \\
\mathrm{E} \\
\mathrm{D}\end{array}$ & & & & -0.05 & 0.002 & -0.13 & $-0.64^{* *}$ & 0.30 & 0.38 & 0.24 & 0.20 & -0.09 & -0.28 & 0.26 & $-0.55^{* *}$ & -0.28 & -0.32 \\
\hline $\begin{array}{l}\mathrm{F} \\
\mathrm{P} \\
\mathrm{M}\end{array}$ & & & & & $0.90^{* *}$ & 0.15 & $0.63^{* *}$ & $0.53^{* *}$ & $0.52^{* *}$ & $0.58^{* *}$ & $0.55^{* *}$ & $0.42^{*}$ & 0.35 & 0.19 & 0.18 & -0.14 & 0.03 \\
\hline $\begin{array}{l}\mathrm{B} \\
\mathrm{D} \\
\mathrm{M}\end{array}$ & & & & & & -0.29 & $0.42^{*}$ & $0.66^{* *}$ & $0.66^{* *}$ & $0.62^{* *}$ & $0.59^{* *}$ & 0.33 & 0.26 & 0.29 & 0.16 & 0.01 & 0.07 \\
\hline $\begin{array}{l}\text { B } \\
\text { W }\end{array}$ & & & & & & & $0.45^{*}$ & -0.36 & -0.36 & -0.169 & -0.18 & 0.13 & 0.09 & -0.30 & 0.04 & -0.36 & -0.04 \\
\hline $\begin{array}{l}S \\
T\end{array}$ & & & & & & & & 0.07 & 0.04 & 0.22 & 0.22 & 0.34 & $0.40^{*}$ & -0.05 & $0.49^{*}$ & 0.02 & 0.07 \\
\hline $\begin{array}{l}\mathrm{P} \\
\mathrm{M} \\
\mathrm{S}\end{array}$ & & & & & & & & & $0.98^{*}$ & $0.89^{*}$ & $0.87^{*}$ & 0.30 & 0.26 & $0.77^{* *}$ & 0.07 & 0.13 & -0.26 \\
\hline $\begin{array}{l}\text { V } \\
P \\
\text { S }\end{array}$ & & & & & & & & & & $0.91^{* *}$ & $0.89^{* *}$ & 0.36 & 0.28 & $0.80^{* *}$ & 0.06 & 0.14 & -0.31 \\
\hline $\begin{array}{l}\mathrm{P} \\
\mathrm{M}\end{array}$ & & & & & & & & & & & $0.99^{* *}$ & $0.67^{* *}$ & $0.60^{* *}$ & $0.89^{* *}$ & 0.26 & 0.29 & -0.37 \\
\hline $\begin{array}{l}\text { P } \\
\text { V }\end{array}$ & & & & & & & & & & & & $0.70^{* *}$ & $0.65^{* *}$ & $0.91^{* *}$ & 0.27 & 0.33 & -0.38 \\
\hline $\begin{array}{l}\mathrm{Y} \\
\mathrm{P} \\
\mathrm{S}\end{array}$ & & & & & & & & & & & & & $0.94^{* *}$ & $0.67^{* *}$ & $0.41^{*}$ & 0.39 & -0.29 \\
\hline $\begin{array}{l}\text { Y } \\
\text { V }\end{array}$ & & & & & & & & & & & & & & $0.63^{* *}$ & $0.43^{*}$ & $0.43^{*}$ & -0.23 \\
\hline $\begin{array}{l}\text { Y } \\
\text { S } \\
F\end{array}$ & & & & & & & & & & & & & & & 0.22 & $0.46^{*}$ & $-0.46^{*}$ \\
\hline $\mathrm{L}$ & & & & & & & & & & & & & & & & $0.74^{* *}$ & -0.11 \\
\hline C & & & & & & & & & & & & & & & & & -0.31 \\
\hline
\end{tabular}

ED - equatorial diameter $(\mathrm{cm})$; LD - longitudinal diameter (cm); LD / ED - longitudinal / equatorial diameter ratio; FM - fruit mass (g); FPM - fresh shell mass (g); BDM - bark dry mass (g); BW - bark water content (g); ST - shell thickness (mm); SPV - volume of pulp with seed and PV - without seed (mL); PMS - pulp mass with seed and PM - seedless (g); YV - yield of seedless pulp volume in relation to seed pulp (\%); YPS - yield of pulp without seed in relation to pulp with seed (\%); YSF - yield of seedless pulp mass in relation to fruit mass (\%); L - luminosity; C - chroma -; hue - angle hue $\left({ }^{\circ}\right)$. ${ }^{* *}$, ${ }^{*}$ Significant at $1 \%$ and $5 \%$ probability, respectively.

alata elite genotypes, because their peel and seeds are edible (FALEIRO et al., 2017). Regarding the water content of the shell, VASCONCELLOS et al. (2001) also verified the water contents close to the obtained ones to be an average of $90 \%$. Although, the fruits of elite genotypes G4 and G8 showed lower water content in their shell, the percent differences of approximately $1.72 \%$ were insufficient to interfere with the fruit mass value (Table 2).
According to table 4, the seedless pulp yield relative to the seed pulp (YPS), as well as the seedless pulp yield relative to the seed pulp (YV) did not differ significantly among the elite genotypes. Regarding the peel color (Table 5), the fruits did not differ with respect to the hue angle that defines the shade of the peel, which indicates that the fruits have a yellow color. However, the fruits differ in the saturation of this color, where the fruits of the elite 
4 genotype were less saturated; in other words, they tended to be lesser greyish in color as compared to the fruits of G6. As for luminosity, it was observed that the fruits of G6 had less luminosity.

The brightness of the shell showed positive and significant correlations (0.49) with the thickness of the shell in the tested cases. The elongated fruits showed a negative correlation with the thickness of the peel and with the luminosity of the fruit peel, which indicated that the brightness of the shell is related to the shell thickness. Both the peel color and pulp yield (YSF) showed negative correlations with the hue angle and positive with chroma; however, as depicted in table 7, the hue angle had the lowest relative contribution among all tested characteristics.

Pulp yield relative to fruit (YSF) showed a positive correlation with the fruit mass, and all other yield characteristics (such as YV and RM), pulp mass, and volume. This finding is interesting in terms of plant selection, especially when targeting a larger amount of pulp by selecting larger fruits.

ALVES et al. (2012) also noted several significant correlations among the various physical and chemical characteristics that were analyzed, and emphasized that simple evaluations, such as that of the fruit size, can be used to estimate the yield parameters during the selection processes of sweet passion fruits.

Multivariate analyses were performed to study the genetic variability of the 8 elite genotypes that showed a tendency to group elite genotypes based on their fruit shape and a greater distance between the elite genotypes 6 and 8 when compared to the others (Figure 2).

The histogram in figure $2 \mathrm{a}$ illustrates 3 groups: one group consists of genotypes G1, G3, and G4 that have more rounded shapes, another group with genotypes G2, G5, and G7, and a third group of genotypes G6 and G8.

However, as shown in figure $2 \mathrm{a}$, the first 2 groups are closer, while the third group is farther apart and, within it, the genotypes G6 and G8 are also far apart. This distance between G6 and G8 genotypes is due to some differences such as pulp mass, shell thickness, longitudinal and equatorial diameter, shell thickness and water content.

Table 7 depicts the percent of the relative importance of traits as described by SINGH (1981), which indicates the extent of contribution of each trait to the divergence among the $P$. alata elite genotypes.

The characteristics that most contributed to the differentiation of elite genotypes were pulp mass (PM) and seedless pulp volume (PV). The characteristics that contributed the least were the color of the bark (Hue) and the water content of the bark (BW).

Although, the fruit mass presented with a low relative importance in the divergence of the elite genotypes (Table 6), this characteristic showed a significant positive correlation (Table 7) with the characteristics of higher contribution.

Considering the 23 characteristics (such as those related to plants, leaves, flowers, fruits, seeds, chemical characteristics of fruits, and

Table 7 - The relative contribution of traits to divergence - SINGH (1981), from 8 elite genotypes of the Passiflora alata Curtis. in a descending order of importance.

\begin{tabular}{|c|c|c|c|}
\hline features & Singh $(\%)$ & features & Singh $(\%)$ \\
\hline Seedless pulp mass (g) & 20.93 & Longitudinal diameter $(\mathrm{cm})$ & 1.32 \\
\hline PV (mL) & 20.81 & Fresh Peel Pasta (g) & 1.27 \\
\hline YPS $(\%)$ & 17.36 & Fruit mass (g) & 0.70 \\
\hline YV $(\%)$ & 11.82 & VPS (mL) & 0.70 \\
\hline YSF (\%) & 7.09 & Chroma & 0.70 \\
\hline Lightness & 4.77 & Equatorial Diameter $(\mathrm{cm})$ & 0.41 \\
\hline Pulp mass with seeds (g) & 4.63 & Bark dry mass (g) & 0.19 \\
\hline Shell thickness (mm) & 4.26 & Bark water content $(\%)$ & 0.14 \\
\hline $\mathrm{LD} / \mathrm{ED}$ & 2.81 & Hue angle $\left({ }^{\circ}\right)$ & 0.004 \\
\hline
\end{tabular}

PV - pulp volume without seed; YPS - yield of pulp without seed in relation to pulp with seed; YV - yield of seedless pulp volume in relation to seeded pulp; YSF - yield of seedless pulp mass in relation to fruit mass; LD / ED - longitudinal / equatorial diameter ratio; VPS - volume of pulp with seed. 


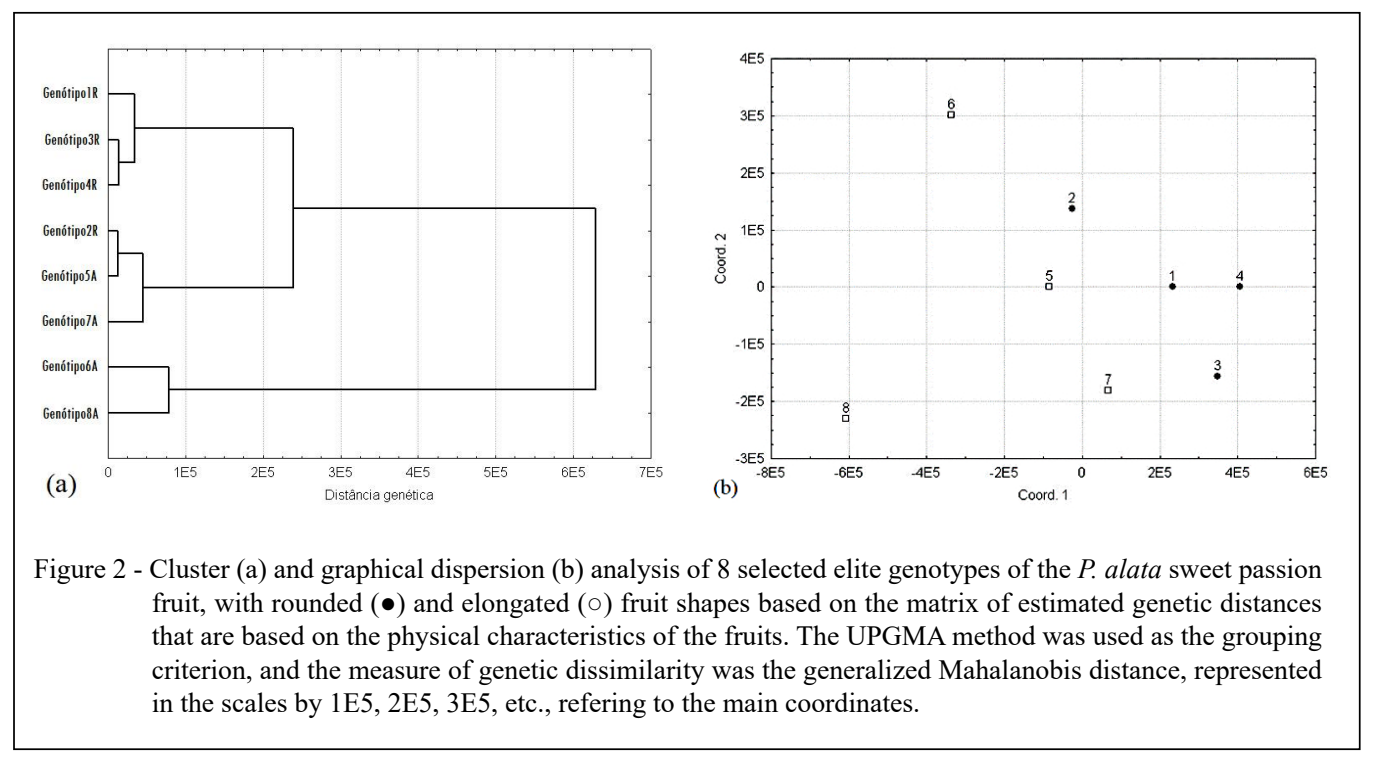

production) of Passiflora cincinnata, ARAÚJO et al. (2008) reported that the largest contribution was the total fruit production (42.29\%), and the relative contribution of fruit mass was $4.03 \%$, shell thickness $2.48 \%$, equatorial diameter $0.43 \%$, and longitudinal diameter $0.15 \%$.

OLIVEIRA et al. (2017) rated 15 hits from Passiflora spp. and verified that the largest contribution $(51.3 \%)$ was provided by the shell mass when the 14 characters related to flowers, fruits, and physicochemical characteristics of fruits were considered. For the P. alata elite genotypes, the bark mass characteristics had the smallest contribution to genetic divergence (Table 6). Thus, the major or minor contribution of each fruit physical characteristics tested to the divergence depended on the species and their elite genotypes.

\section{CONCLUSION}

Significant differences were recorded between the elite genotypes for most fo the tested physical characteristics of fruits in this study. Of the 8 , elite 7 genotype presented with the highest juice yield in relation to the fruit, being the second-largest fruit mass. Graphical dispersion revealed a tendency of grouping of elite genotypes based on their round fruit shape. The study population showed genetic variability, allowing new selection and recombination cycles to gain pulp yield and fruit mass. The elite 6 and
8 genotypes were reported to be the most divergent among the other genotypes. These 2 elite genotypes should; therefore, be considered as parent plants in further studies of general and specific combining ability with other selected breeds for productivity and disease resistance within the breeding program.

\section{ACKNOWLEDGEMENTS}

This study was funded by the Coordenação de Aperfeiçoamento de Pessoal de Nível Superior (CAPES - Finance code 001 ) of the Conselho Nacional de Desenvolvimento Científico e Tecnológico (CNPq). The author ACAD thanks CAPES for granting the scholarship and University of Brasilia (UnB) for learning opportunity. The authors thank the students / trainers and all of Embrapra's collaborators who contributed to this work.

\section{DECLARATION OF CONFLICT OF INTERESTS}

The authors declare no conflict of interest. The founding sponsors had no role in the design of the study; in the collection, analyses, or interpretation of data; in the writing of the manuscript, and in the decision to publish the results.

\section{AUTHORS' CONTRIBUTIONS}

FGF and AMC conceived, supervised and coordinated the experiments in field. AMC, FGF, NTVJ and MFB conceived and designed the plant selection experiments in field. ACAD performed the carried out the lab analyses and prepared the draft of the manuscript. ACA e FGF performed statistical analyses of experimental data. All authors critically revised the manuscript. 


\section{REFERENCES}

ALVES, R.R. et al. Relations among physical and chemical characteristics of sweet passion fruit cultivated in Viçosa, MG. Revista Brasileira de Fruticultura, Jaboticabal, v.34, n.2, 2012 p.619-623. Available fom: <http://dx.doi.org/10.1590/S010029452012000200038>. Accessed: Dec. 26, 2018. doi: 10.1590/ S0100-29452012000200038.

ARAÚJO, F.P. et al. Genetic divergence among Passiflora cincinnata mast accessions based on morphoagronomic descriptors. Revista Brasileira de Fruticultura, Jaboticabal, v.30, n.3, 2008. p.723-730. Available from: <http://dx.doi.org/10.1590/ S0100-29452008000300027>. Accessed: 26 Dec. 26, 2018. doi: $10.1590 / \mathrm{S} 0100-29452008000300027$

BRAGA, M.F. et al. Maracujá-doce: Melhoramento genético e germoplasma. In: FALEIRO, F.G. et al. Maracujá: germoplasma e melhoramento genético. Planaltina: Embrapa Cerrados, 2005. p. 600-616.

CEASA - Centrais de Abastecimento do Estado de Goiás. A força do abastecimento no coração do Brasil. Análise Conjuntural 2017. n.42 Governo do Estado de Goiás, 2017. Available from: <http://www.sgc.goias.gov.br/upload/arquivos/2018-06/ conjuntura-anual-2017-numerada_compressed.pdf $>$. Accessed: Dec. 16, 2018

COSTA, A.M. Propriedade das passifloras como medicamento e alimento funcional. In.: JUNGHANS, T.G.; JESUS O.N. Maracujá do cultivo à comercialização. Embrapa; cap.13, 2017. p.299-318.

CRUZ, C.D. GENES - a software package for analysis in experimental statistics and quantitative genetics. Acta Scientiarum Agronomy, Maringá, v.35, n.3, p.271-276, 2013. Available in: $<$ http://dx.doi.org/10.4025/actasciagron.v35i3.21251>. Accessed: Dec. 26, 2018. doi: 10.4025/actasciagron.v35i3.21251.

FALEIRO, F.G. et al. Importância socioeconômica de cultural do maracujá. In: FALEIRO, F. G.; JUNQUEIRA, N.T.V. (editores). Maracujá: O produtor pergunta, a Embrapa responde. Brasília, Embrapa, 2016. p.16-21 (Coleção 500 perguntas, 500 respostas).

FALEIRO, F.G. et al. BRS Mel do Cerrado: Cultivar de maracujazeirodoce (Passiflora alata Curtis) para o mercado de frutas especiais de alto valor agregado. 2017. (Folder). Available in: $<$ http://www. cpac. embrapa.br/publico/usuarios/uploads/lancamentomeldocerrado/ fodercultivar.pdf)>. Accessed on: 21 Dec. 2017.

FERREIRA, F.R. Recursos genéticos de Passiflora. In: FALEIRO, F.G. et al. Maracujá: germoplasma e melhoramento genético. Planaltina: Embrapa Cerrados, 2005. p. 41-51.

FERREIRA, M.E.; RANGEL, P.H.N. Emprego de espécies silvestres no melhoramento genético vegetal: experiência em outras espécies com análise de retrocruzamento avançado de QTLs (AB-QTL). In.: FALEIRO, F.G. et al. Maracujá: germoplasma e melhoramento genético. Planaltina: Embrapa Cerrados, 2005. p.111-140.
JUNQUEIRA, N.T.V. et al. Potencial de espécies silvestres de maracujazeiro como fonte de resistência a doenças. In.: FALEIRO, F. G. et al. Maracujá: germoplasma e melhoramento genético. Planaltina: Embrapa Cerrados, 2005. p. 81-108.

MACHADO, C.F. et al. Espécies silvestres de maracujazeiro comercializadas em pequena escala no Brasil. JUNGHANS, T.G.; JESUS, O.N. (Eds.) Maracujá: do cultivo à comercialização. Brasília, DF: Embrapa, 2017. p.59-80.

MARTINS, M.R. et al. Evaluation of sweet passion fruit (Passiflora alata Curtis) populations obtained by open polinization. Revista Brasileira de Fruticultura, Jaboticabal, v.25, n.1, 2003. p.111-1147. Available from: <http://dx.doi.org/10.1590/S010029452003000100032>. Accessed: Dec. 26, 2018. doi: 10.1590/ S0100-29452003000100032.

MCGUIRE, R.G. Reporting of objective colour measurements. HortScience, v.27, p.1254-1255, 1992. Available in: <http:// hortsci.ashspublications.org/content/27/12/1254.full.pdf + html $>$. Accessed: Dec. 26, 2018.

MELETTI, L. M. M. et al. Genetic variabilitty of morphological, agronomic and cytogenetics characters of sweet passion-fruit populations (Passiflora alata Curtis). Revista Brasileira de Fruticultura, Jaboticabal, v.25, n.2, 2003.p.275-278. Available in: $\quad<$ http://dx.doi.org/10.1590/S0100-29452003000200023>. Accessed: Dec. 26, 2018. doi: 10.1590/S010029452003000200023.

OLIVEIRA, J.S. et al. Genetic and morphoagronomic diversity of Passiflora spp. based on quantitative measurements of flowers and fruits. Revista Brasileira de Fruticultura, v.39, n.1, 2017. p.1-7. Available from: <http://dx.doi.org/10.1590/0100-29452017003>. Accessed: Dec. 26, 2018. doi: 10.1590/0100-29452017003.

REFLORA - PASSIFLORA in Flora do Brasil 2020 em construção. Jardim Botânico do Rio de Janeiro. Available from: $<$ http://floradobrasil.jbrj.gov.br/reflora/floradobrasil/FB12506>. Accessed: Apr. 10, 2018.

SAS INSTITUTE. SAS user's guide: statistic: version 9.1.3. Cary: SAS Institute, 2008. 846 p.

SINGH, D. The relative importance of characters affecting genetic diversity. Indian Journal of Genetics and Plant Breeding, New Delhi, v.41, n.2, p.237-245, 1981. Available from: <http://www. indianjournals.com/ijor.aspx?target=ijor:ijgpb\&volume $=41 \&$ issue $=2 \&$ article $=010>$. Accessed: Dec. 26, 2018 .

STATSOFT, Inc. Statistica for Windows (data analysis software system), version 7.1. Statsoft, Tulsa, Oklahoma (USA), 2005.

VASCONCELLOS, M.A.S. et al. Caracterização física e quantidade de nutrientes em frutos de maracujá doce. Revista Brasileira de Fruticultura, Jaboticabal, v.23, n.3, 2001. p.690-694. Available in: <http://dx.doi.org/10.1590/S010029452001000300049>. Accessed: Dec. 26, 2018. doi: 10.1590/ S0100-29452001000300049. 